UDK: $336.711(497.7)$

DOI: $10.1515 / j c b t p-2017-0020$

Journal of Central Banking Theory and Practice, 2017, 3, pp. 35-65

Received: 6 September 2016; accepted: 17 October 2016

Anita Angelovska Bezhoska*

\section{Central Bank Independence - the Case of the National Bank of Republic of Macedonia'}

\begin{abstract}
This paper explores the level of independence of the National bank of the Republic of Macedonia by primarily focusing on the legal provisions that pertain to the key aspects for achieving and maintaining price stability. It provides a historical perspective of the evolution of the independence since the first years of transition. The assessment of the independence of the NBRM is based on the index of Cukierman, Webb, and Neyapti (1992), as one of the most commonly used indices, and the index of Jacome and Vazquez (2005), which incorporates some specific aspects relevant for transition economies. Both indices indicate that the legal independence of the NBRM has increased over the years and that the current legal framework provides a high level of independence. Yet, it should be emphasized that there is a room for further strengthening, in particular in the areas of policy formulation and the process of appointment of the non-executive members of the council of the NBRM. As the indices are based on the legal provisions, they can serve only as an indication of the actual independence of the central bank.
\end{abstract}

JEL Classification Numbers: E42, E58

Keywords: central bank independence, monetary policy, indices, Macedonia

1 The views expressed in this paper are those of the author and do not necessarily represent the views of the National Bank of the Republic of Macedonia
${ }^{*}$ National Bank of the Republic of Macedonia.

E-mail:

AngelovskaBA@nbrm.mk 


\section{Introduction}

Central bank independence is considered a key precondition for achieving central bank primary objective of price stability. Adequate institutional mechanisms that safeguard central bank from short-term political considerations are instrumental in preserving central bank's control over monetary aggregates, credibility of central bank, and subsequently price stability. Current trends regarding the institutional arrangements point toward an institutional separation of monetary and fiscal policy responsibilities accompanied with a high level of independence for the central banks that can be seen as a protection against imprudent fiscal policy.

This paper aims at assessing the level of independence of the National Bank of the Republic of Macedonia (hereinafter: NBRM) by primarily focusing on the legal provisions that pertain to the key aspects for achieving and maintaining price stability. Thus, the focus is placed on the central bank objectives, the authority to determine and implement monetary and foreign exchange policies, appointment and dismissal of top personal of the bank, relations with the government and the parliament, limitations on government financing and other legal dimensions that determine the strength of the mandate and the independence of the central bank. The analysis provides a historical perspective of the evolution of the independence since the first years of transition. The first Law on the NBRM was passed in 1992 establishing the NBRM as the central bank of the newly established independent state. With a view of strengthening the independence of the central bank, the legal framework was amended a number of times, including the adoption of a new central bank law in 2002 and subsequently in 2010 .

The reminder of the paper is organized as follows. Second section provides a review of theoretical and empirical literature on central bank independence. Third section provides an assessment of the level of the NBRM independence through two commonly used indices for assessment of the legal independence-index of Cukierman, Webb and Neyapti (1992) and the index of Jacome and Vazquez (2005). Actual independence is proxied by the turnover rate of governor. Fourth section presents inflationary developments in the Macedonian economy. The last section gives a conclusion. 


\section{Review of theoretical and empirical literature on central bank independence}

A considerable amount of theoretical and empirical literature has been published on independence of central banks. Unlike fiscal policy, monetary policy is delegated to an independent institution whose top officials are with longer term of office than the political cycle. The great depression and the collapse of the gold standard resulted in a widespread government takeover of monetary policy where the determination of the official interest rate was a government exercise (Goodhart, 2010). Until mid-1980s most of the central banks were subordinated to the governments and functioned almost like divisions of the ministry of finance being in charge of different functions, including financing of the government deficit. This was a period marked by sustained periods of high inflation. The trend of delegation of monetary policy to an independent institution started in the 1980s and was especially pronounced during the 1990s based on three foundations: the success of the Bundesbank in controlling inflation and success of the German economic model, theoretical literature on the inflationary bias of the discretionary monetary policy, and empirical literature on the relationship between central bank independence and macroeconomic aggregates (Debelle \& Fischer, 1994). There was an understanding that monetary authority can successfully implement and maintain society's desirable target path for price stability if it has a clear mandate and is independent in deciding how to implement monetary policy (Niemann \& von Hagen, 2008).

Although the need for delegation of the monetary policy has not been generally questioned in the theory and practice, yet there are different theoretical views on the reasons for the delegation. A group of theories for central bank independence point to the time-inconsistency problem and inflation bias of the government as main reasons for the delegation. The time-inconsistency problem, as described by Kydland and Prescott (1977) and Barro and Gordon (1983), arises because the politicians try to use the short-run trade-off between inflation and unemployment to increase the employment in the short run. However, expansionary policies will make economic agents adjust wage and price expectations leading to higher inflation and lower growth in the long run. Having in mind that monetary policy is "...not a game against nature, but, rather, a game against rational economic agents" (Kydland \& Prescott, 1977, p.473), policy credibility has received a huge attention in the theory and practice. Barro and Gordon (1983) claim that optimal monetary policy (non-inflationary) cannot be credible as long as monetary shocks can be used by the policymakers to boost output above its equilibrium or reduce the real value of the government's nominal liabilities. Although surprise inflation will bring short-term benefits, there are long-term costs. 
Some of the proposed solutions in the literature for overcoming the time-inconsistency problem are having formal commitments for the conduct of policies or anti-inflationary reputation of the policymaker that can substitute for formal commitments. Barro and Gordon (1983) develop a reputational equilibrium where the optimal outcomes (inflation and monetary growth) turn out to be weighted averages of those from discretion and those from ideal rules. Rogoff (1985) considers an intuitional response to the time-inconsistency problem by proposing an appointment of a conservative central banker to conduct monetary policy, i.e. a central banker who does not share the social objective function. The society can be better off by having a central banker who places "too large" a weight on stabilization of inflation relative to employment stabilization. However, the society would not want the weight to be infinitive. Rogoff's approach can be interpreted as advocating for goal and instrument independence.

Mishkin (2011) finds two problems with the Rogoff's proposal. First, it is undemocratic to impose different preferences from those of the public. And second, a central bank cannot operate in the long run without a support of the public. Instead, he proposes having an institutional commitment to price stability set in the legislation for the central bank. Once politicians commit to price stability it will be more difficult for them to exert pressures over the central banks for more expansionary policies. In addition, it will mean that price stability is an overriding objective and fiscal policy will have to be better aligned with monetary policy. Thus, Mishkin advocates for goal dependence, but instrument independence. Another approach for solving the dynamic inconsistency problem is the principal-agent approach proposed by Walsh (1998) and Persson and Tabellini (1993). They advocate for structuring a contract for objectives of the monetary policy that imposes costs on the central bank when objectives deviate from the pre-defined level. According to this approach, central bank is assigned instrument independence, and not goal independence.

Laurens and Piedra (1998) claim that in a system where there is not an independent central bank with a clear objective of price stability, in case of a conflict between policies, the central bank may be subject to political pressures, and short-term considerations could take preeminence over long-term. Under such frameworks, clear legal arrangements (formal rules) should be in place to prevent or resolve conflicts, including limitation to direct central bank credit to the government, deficit and debt limitation clauses.

According to the political agency theory of central bank independence (Eggertsson \& Borgne, 2003), the rationale for delegation is not the time inconsistency problem and inflation bias, but a long term job contract of the central banker that 
creates an incentive to put more effort in policy decision-making. As a consequence, there are better forecasts of the state of the economy and fewer mistakes in the conduct of the monetary policy, which increases social welfare. This theory focuses on the complexity of the task itself and on the level of rent the politicians derive from managing this policy. It argues that monetary policy is subject to considerable uncertainty compared to other policies and that rents that politicians can derive from monetary policy are most likely lower compared to the rents from fiscal policy. As for the types of independence, it argues that while instrument independence is desirable, goal independence is not. The reason for delegation stated by this theory is consistent with Alan Blinder's view (1998) that monetary policy, by its very nature, requires a long time horizon.

The level of central bank independence is usually measured through indices that typically reflect legal aspects of independence. The most commonly used are the indices of Grilli, Masciandaro, \& Tabellini (1991), Cukierman (1992), and Cukierman, Webb, \& Neyapti (1992). Grilli, Masciandaro, \& Tabellini (1991) constructed an economic independence index (mainly referring to the possibility and types of direct crediting of the government by the central bank) and a political independence index (mainly referring to goal autonomy, terms of appointment of the governor and other top officials of the central bank). Cukierman et al. (1992) constructed a very detailed index on legal independence of the central banks in the industrial and developing economies applying 16 criteria grouped in 4 classes (goal independence, autonomy of the governor, independence in formulating monetary policy, and central bank credit to the government). They ranked the central banks of Germany, Switzerland and Austria at the top of the list of the independent central banks and Poland, Morocco and former Yugoslavia at the bottom of the list. These indices were often modified to reflect specifics of economies, in particular the specific features of the transition economies. The indices of Grilli, Masciandaro, \& Tabellini (1991) were modified by Maliszewski (2000) and Lybek (1999). The index of Cukierman et al. (1992) was modified by Neyapti (2001) and Jacome and Vazquez (2005).

The independence of central banks and the link between independence and inflation in transition economies has been subject to a wide theoretical and empirical research. At the onset of the transition, most of the economies faced with hyperinflationary environment. Against such backdrop, higher independence of the central bank can increase credibility of macroeconomic policies and contribute to the stabilization process. The level of independence reflects the society's aversion to inflation. Wagner (1997), analysing the preconditions for successful disinflation in the transition economies, stresses the importance of the institutional requirements including central bank independence. Wagner (1999) also points to 
the distinction between the legal and actual independence, as legal independence without actual independence may even be counterproductive (the government may blame the central bank for an unsuccessful disinflation process).

The descriptive studies by Hinton-Braaten (1994), Hochreiter (1994), Hochreiter and Riesinger (1995) and Radzyner and Riesinger (1997) were some of the first studies dealing with this issue in transition economies. Dvorsky (2000) explores legal independence of the central banks of 5 transition economies - Czech Republic, Hungary, Poland, Slovakia, and Slovenia by applying two widely used indices: the Cukierman (1992) and Grilli, Masciandaro, \& Tabellini (1991). She concludes that overall degree of legal independence is comparatively high in all 5 countries, with Poland showing the best results according to the both indices (pointing to a significant progress during the transition process).

Maliszewski (2000) investigates legal independence for 20 transition countries in Central and South-eastern Europe, including the Republic of Macedonia (hereinafter: RM). The main characteristics of independence are coded in the indices similar to the Grilli-Masciandaro-Tabellini indices divided into two components: political and economic independence. The author finds that the average level of independence for all countries is high pointing out that six countries in the group (including the RM) have higher independence than the Bundesbank. However, independence is not a substitute for other elements of the stabilization programs and exerts a downward pressure on inflation only at the high level of price liberalization (after the initial price liberalization shock has been contained).

The study of Cukierman, Miller, \& Neyapti (2002), covering 26 former socialist economies (including the RM) during 1991-1998, finds that the central bank reforms in these economies during the 1990s were ambitious, which is visible through higher (on average) levels of independence of these economies than those of developed economies during the 1980s. They find that legal independence becomes effective in controlling inflation, but only after the process of price liberalization takes momentum, as it can have a powerful inflationary impact. Negative correlation between the legal independence and inflation is also found by Loungani and Sheets (1997) and Eijffinger and Stadhouders (2003).

Dvorsky (2004 and 2007) examines the functional, institutional, personal and financial independence of 8 South-eastern European countries, including the RM, by applying the EU Treaty provisions as benchmarks. Countries joining the EU after the establishment of the European System of Central Banks have to adjust their central bank independence legislation by the EU accession date. The author finds that the level of independence in these countries largely corresponds to their 
level of EU integration. Main weaknesses are identified in the area of personal independence (largely provisions on dismissal of the central bank top officials) and monetary financing area where adjustments are needed for alignment with the EU requirements. Regarding the independence of the NBRM (assessed on the basis of the legal framework in force in 2002), major issues raised are in the areas of: (i) institutional independence (monetary program has to be sent on an ex ante basis to the parliament which may imply political influence; the parliament has a final say in case the Council of the bank cannot achieve the required majority for decision-making); and (ii) personal independence (the rules for dismissal of the central bank top officials).

Bogoev (2007) explores the level of central bank independence in 9 South-eastern economies by applying Grilli, Masciandaro, \& Tabellini (1991), Cukierman et al. (1992) and a modified version of Cukierman et al. (1992) index by Jacome and Vazquez (2005). Overall assessment is that all analyzed countries have a relatively high level of legal central bank independence and that the level of independence is higher compared to previous studies pointing out that legal framework has been improved to strengthen the institutional independence. According to the Cukierman et al. index (1992) the independence of the NBRM is ranked at fourth position behind Bosnia and Herzegovina, Bulgaria, Croatia and Romania (Bulgaria and Croatia share the second position). The modified version of this index places the RM at third position.

Jankoski (2010) also finds a high level of legal independence of the NBRM by applying indices of Bade and Parkin (1988), Eijffinger and Schaling (1993), Grilli, Masciandaro, \& Tabellini (1991) and Cukierman et al. (1992). The same conclusion is valid for the actual independence that he measures through two approaches: turnover rate of governors and the survey of Cukierman (1992).

It is important to note that empirical results should be treated with a certain degree of caution. Most of the studies to assess the level of independence and the relation between the independence and the inflation and other macroeconomic indicators are based on the legal independence, assuming that it is a good proxy for the actual one. However, there might be a substantial difference between the legal and actual independence. "Actual, as opposed to formal, central bank independence depends not only on the law, but also on many other less-structured factors, such as informal arrangements between the bank and other parts of government, the quality of the bank's research department, and the personality of key individuals in the bank and the (rest of the) government." (Cukierman, 1992, p.355) Also, the assessment of independence includes many subjective elements. Furthermore, there is a problem of causality. Namely, societies that show a higher 
degree of public aversion towards inflation create independent central banks, so in such cases the conclusion may be that low inflation is not a direct result of an independent central bank, but another factor that explains it, i.e. a high degree of public aversion leads to independent central bank and low inflation.

\section{Assessment of independence of the NBRM}

The assessment of the NBRM independence is based on the index of Cukierman et al. (1992) (hereinafter: the Cukierman index), as one of the most commonly used indices, and the modified Cukierman index of Jacome and Vazquez (2005) (hereinafter: the MCI). The indices assess the legal aspect of independence as one of the main components of actual independence, though the latter depends on many other additional factors. The measurement is based on the legal provisions of the charter of the central bank that regulate its mandate, authority, tasks and operations and does not reflect the aspect of practical implementation of the legal provisions. Unlike the other research papers that assess the independence of the NBRM at a certain period of time, this paper provides a historical perspective through measurement of the level of independence granted by the NBRM Law adopted in 1992, the one adopted in 2002, and the law adopted in 2010. Also, the turnover rate of governors is calculated as a rough proxy of the actual independence.

\section{A. Cukierman Index}

The Cukierman index uses 16 legal variables in the following 4 clusters: chief executive officer (appointment, dismissal, term of office, holding offices in government), monetary policy formulation (the authority to make decisions on monetary policy, resolution of conflicts regarding monetary policy and involvement of the central bank in the budgetary process), objectives of the central bank, and limitations on the central bank lending to the government (securitized and nonsecuritized lending, potential borrowers, terms and conditions of lending).

The scale of coding is from 0 (lowest level of independence) to 1 (highest level of independence). A higher number points to stronger mandate and independence of the central bank from the executive branch in pursuing price stability. Coding for the first group of variables depends on the government's involvement in the process of appointment and dismissal of the governor and his/her term of office. A lower involvement of the government and a longer term of office imply a higher isolation of the monetary policy from short-term political considerations that 
may endanger price stability. Similarly, a lower involvement of the government in monetary policy formulation (second group) indicates higher central bank independence. Rating of the objectives (third group) depends on the prominence assigned to price stability in relation to other objectives that might conflict with price stability. A higher rating for limitations on lending (the last group) is assigned when the lending to government is not allowed or is allowed under tight limits. Also, the stricter the terms of lending (interest rate, maturity, collateral), the higher is the value of that variable. Legal limitation on the central bank financing of the government is considered instrumental in safeguarding the control of the central bank over monetary aggregates and inflation. Its importance is even more emphasized for transition economies with undeveloped financial markets where the need for central bank financing is higher.

The aggregate Cukierman index of independence is calculated as a weighted average of the values assigned to the individual variables. The highest weight is assigned to the group of variables relating to limitations on lending to the government (50 percent), chief executive officer group of criteria has a weight of 20 percent, and policy formulation and objectives group have 15 percent, each. For the chief executive officer, the coding at the level of the group is derived as a simple average of the coding of the four variables in the group. The coding for the policy formulation group is derived as a weighted average of the codes of each individual variable in the group. Each of the 8 variables in the group on lending to government is assigned an individual weight.

Generally, the Cukierman index indicates that throughout the years the legal independence of the NBRM has increased. The first law on the NBRM adopted in 1992 granted only a moderate level of independence with the value of the aggregate index of 0.60 . The law adopted in 2002 strengthened its mandate and independence as evidenced through the increased value of the index (0.70), and the most recent law adopted at the end of 2010 and subsequently amended a couple of times provides a high level of independence with a value of the index reaching $0.92^{2}$. The index points to a room for further strengthening in the area of appointment, dismissal and terms of office of the governor, and involvement of the central bank in the budgetary process.

2 The assessment of independence granted by the Law on the NBRM passed in 2010 considers also the amendments to the Law adopted in 2012, 2014, and 2015. 
Table 1: Measurement of Independence of NBRM - Cukierman index

\begin{tabular}{|c|c|c|c|c|c|}
\hline $\begin{array}{l}\text { Variable } \\
\text { number }\end{array}$ & Description of variable & $\begin{array}{l}\text { Numerical } \\
\text { coding }\end{array}$ & 2011 & $\begin{array}{l}2002- \\
2010\end{array}$ & $\begin{array}{l}1992- \\
2001\end{array}$ \\
\hline \multirow[t]{25}{*}{1} & Chief executive officer (CEO) & & 0,77 & 0,77 & 0,44 \\
\hline & a. Term of office & & 0.75 & 0.75 & 0.75 \\
\hline & Over 8 years & 1.00 & & & \\
\hline & 6 to 8 years & 0.75 & 0.75 & 0.75 & 0.75 \\
\hline & 5 years & 0.50 & & & \\
\hline & 4 years & 0.25 & & & \\
\hline & Under 4 years or at the discretion of appointer & 0.00 & & & \\
\hline & b. Who appoints CEO? & & 0.50 & 0.50 & 0.50 \\
\hline & Board of central bank & 1.00 & & & \\
\hline & $\begin{array}{l}\text { A council of the central bank board, executive } \\
\text { branch, and legislative branch }\end{array}$ & 0.75 & & & \\
\hline & Legislature & 0.50 & 0.50 & 0.50 & 0.50 \\
\hline & Executive collectively (e.g., council of ministers) & 0.25 & & & \\
\hline & One or two members of the executive branch & 0.00 & & & \\
\hline & C. Dismissal & & 0.83 & 0.83 & 0.50 \\
\hline & No provision for dismissal & 1.0 & & & \\
\hline & Only for reasons not related to policy & 0.83 & 0.83 & 0.83 & \\
\hline & At the discretion of central bank board & 0.67 & & & \\
\hline & At legislature's discretion & 0.50 & & & 0.50 \\
\hline & Unconditional dismissal possible by legislature & 0.33 & & & \\
\hline & At executive's discretion & 0.17 & & & \\
\hline & Unconditional dismissal possible by executive & 0.00 & & & \\
\hline & d. May CEO hold other offices in government? & & 1.00 & 1.00 & 0,00 \\
\hline & No & 1.00 & 1.00 & 1.00 & \\
\hline & Only with permission of the executive branch & 0.50 & & & \\
\hline & No rule against CEO holding another office & 0.00 & & & 0,00 \\
\hline \multirow[t]{16}{*}{2} & Policy formulation & & 0,75 & 0,45 & 0,37 \\
\hline & a. Who formulates monetary policy & & 1.00 & 1.00 & 0,67 \\
\hline & Bank alone & 1.00 & 1.00 & 1.00 & \\
\hline & Bank participates, but has little influence & 0.67 & & & 0,67 \\
\hline & Bank only advises government & 0.33 & & & \\
\hline & Bank has no say & 0.00 & & & \\
\hline & b. Who has final word in resolution of conflict? & & 1.00 & 0.40 & 0.40 \\
\hline & $\begin{array}{l}\text { The bank, on issues clearly defined in the law as its } \\
\text { objectives }\end{array}$ & 1.00 & 1.00 & & \\
\hline & $\begin{array}{l}\text { Government, on policy issues not clearly defined as the } \\
\text { bank's goals or in case of conflict within the bank }\end{array}$ & 0.80 & & & \\
\hline & $\begin{array}{l}\text { A council of the central bank, executive branch and } \\
\text { legislative branch }\end{array}$ & 0.60 & & & \\
\hline & The legislature, on policy issues & 0.40 & & 0.40 & 0.40 \\
\hline & $\begin{array}{l}\text { The executive branch on policy issues, subject to } \\
\text { due process and possible protest by the bank }\end{array}$ & 0.20 & & & \\
\hline & The executive branch has unconditional priority & 0.00 & & & \\
\hline & c. Role in the government's budgetary process & & 0.00 & 0.00 & 0,00 \\
\hline & Central bank active & 1.00 & & & \\
\hline & Central bank has no influence & 0.00 & 0.00 & 0.00 & 0,00 \\
\hline \multirow[t]{7}{*}{3} & Objectives & & 1.00 & 1.00 & 0,60 \\
\hline & $\begin{array}{l}\text { Price stability is the major or only objective in the } \\
\text { charter, and the central bank has the final word in case } \\
\text { of conflict with other government objectives }\end{array}$ & 1.00 & 1.00 & 1.00 & \\
\hline & Price stability is the only objective & 0.80 & & & \\
\hline & $\begin{array}{l}\text { Price stability is one goal, with other compatible } \\
\text { objectives, such as a stable banking system }\end{array}$ & 0.60 & & & 0,60 \\
\hline & $\begin{array}{l}\text { Price stability is one goal, with potentially conflicting } \\
\text { objectives, such as full employment }\end{array}$ & 0.40 & & & \\
\hline & No objectives stated in the bank charter & 0.20 & & & \\
\hline & Stated objectives do not include price stability & 0.00 & & & \\
\hline
\end{tabular}


Table 1: Measurement of independence of NBRM - Cukierman index (continued)

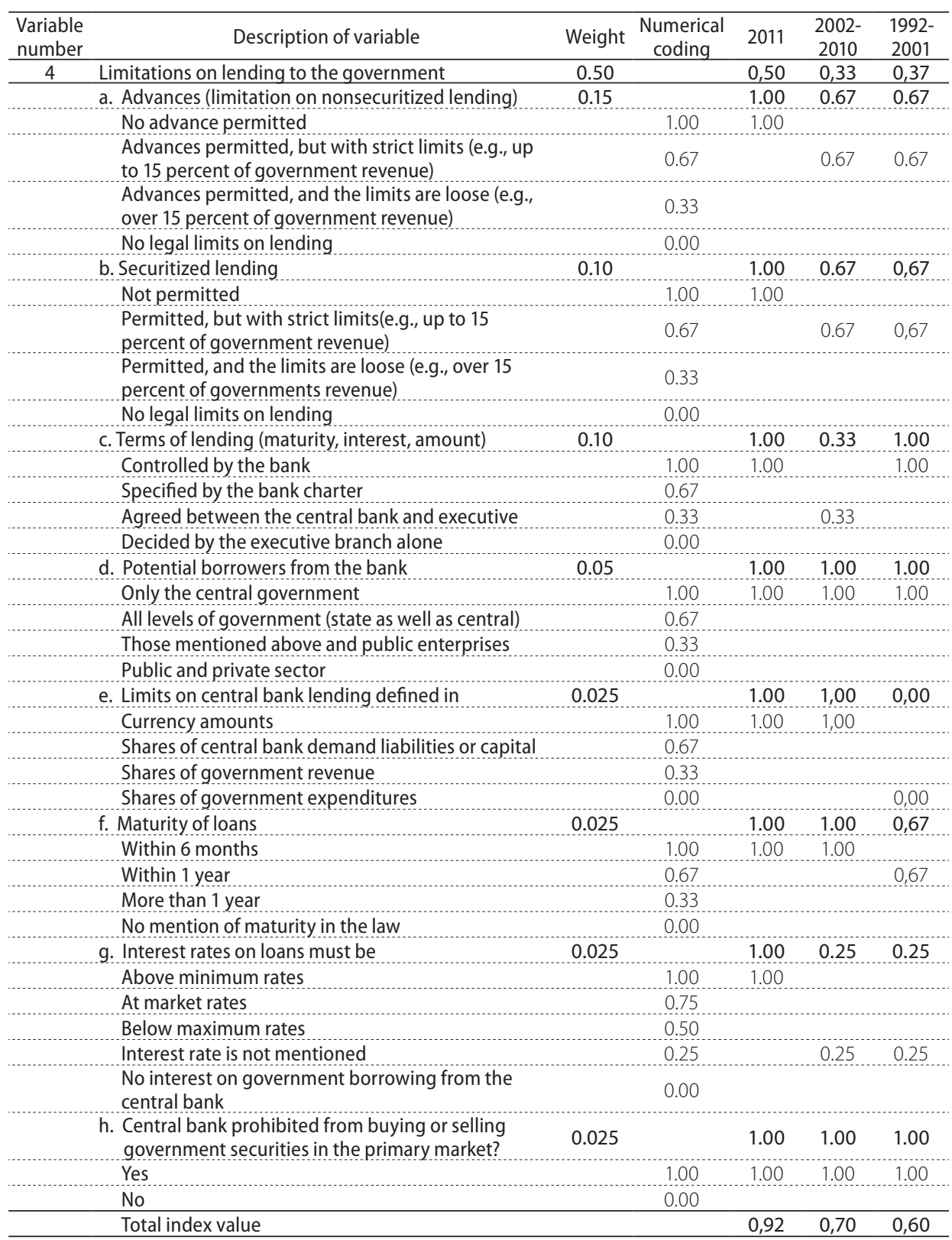

Source: Author's calculations. 
The first Law on the NBRM was adopted in 1992 as a part of the legislative package that laid down foundations for a new monetary system independent of the monetary system of Ex-Yugoslavia. The NBRM was established as the central bank in charge of stability of the Macedonian currency, monetary policy, and stability of domestic and external payments. These three objectives of the central bank were also enshrined in the Constitution. Accordingly, price stability was not explicitly stated as an objective of the central bank nether in the law or in the Constitution. Yet, parliament used to adopt annual decisions on the objectives and tasks of the monetary policy defining price stability as the central bank objective. This pinpoints to some ambiguity and inconsistency regarding the objectives of the bank. Taking into consideration that the parliament's decision defined the price stability as the main objective, the value assigned to this variable is not 0 , but 0.60 .

The formulation of the monetary policy was not solely a responsibility of the central bank. The NBRM was required to prepare an annual projection of monetary and credit aggregates upon which the parliament passed the Decision on the objectives and tasks of the monetary and credit policies for the forthcoming year. The Decision defined numerical targets on inflation and money aggregates consistent with the inflation target. Foreign exchange regime and policy were also decided by the parliament through the Decision on the foreign exchange policy and projection of the balance of payments. The law defined the instruments at disposal of the NBRM to pursue its legal mandate, including reserve requirement, credits to banks and other financial institutions, issuance of central bank bills, definitive or repo transactions with domestic and foreign securities, and interventions in the foreign exchange market. The decisions on the implementation of the monetary and foreign exchange policies were adopted by two thirds of the members of the council of the bank within the framework determined by the parliament. In case of a dispute over monetary and foreign exchange policies, the parliament had the final say. There was no legal requirement for involvement of the central bank in some of the stages of the budget cycle. Preparation, adoption, execution, and oversight of the state budget were responsibilities of the executive and legislative branch. No involvement of the central bank in the budgetary process, as well as the absences of full authority in formulation of the monetary policy and in resolution of conflicts, result in low scoring for the policy formulation group (0.37).

The value for the group chief executive officer is also rather low (0.44). The governor was appointed by the parliament, at a proposal of the president of the state, with a term of office of 7 years with a possibility of being re-elected only once. Re-election was not allowed for the other members of the council. Similarly to 
the appointment process, the dismissal process was to be initiated by the president of the state and decided by the parliament. There were no provisions on the dismissal criteria implying that the parliament had a wide discretion on the dismissal decisions. Also, the law did not have any provisions prohibiting the governor from holding other positions in the government.

Lending to the government was allowed but limited up to $5 \%$ of the budget for the current year. It was not clearly stated whether it refers to the revenue or the expenditure side of the budget, but one may assume that it referred to the expenditure because during this period financing items were treated as revenues, and thus revenue and expenditure side of the budget equalled. Lending had to be in line with the central bank's projection of the monetary and credit aggregates and it was not regulated whether lending can be securitized or non-securitized. There were not much details on the provisions on the terms of lending (interest rate and collateral were not mentioned), but the council of the bank was authorized to decide on the borrowing, including the terms and conditions. The law did not forbid the participation of the central bank in the government primary securities market, but it may be due to the fact that the government's securities market did not exist up till 2004. In light of this, the highest score is assigned for this criterion. Score of 1 is also assigned to the potential borrower criterion as lending was limited to the central government and to the terms of lending criterion as the council was authorized to decide on the terms and conditions of the loans. The lowest value is given to the criterion on the limits to lending as they were not defined in currency amounts, but as a share of budget expenditures.

The law passed in 2002 granted somewhat higher independence to the NBRM as evidenced through the increased value of the aggregate index (from 0.60 to 0.70 ) reflecting improvements in all 4 clusters. The law established price stability as the primary objective of the central bank. In addition, the NBRM was also to supports economic policies and financial stability without jeopardizing its primary objective. This meant that the law was not fully consistent with the Constitution that defined stability of the currency, monetary policy, and stability of domestic and external payments as objectives of the NBRM. Still, the highest value of 1 is assigned to this criterion.

The value for the group of criteria on policy formulation increased from 0.37 to 0.45 driven by the strengthened responsibility of the council for policy formulation. The law granted the full authority to the NBRM for formulating monetary and foreign exchange policy by authorizing the council of the NBRM to pass the Decision on the objectives of the monetary policy, instead of the parliament, although it was presented to the parliament for information purposes. The decision 
defined price stability as the primary objective (although it was already stated in the law) and stability of the currency as intermediary objective in support of the primary objective. The decision initially included numerical targets for inflation and monetary aggregates, but since 2004 it did not include targets on monetary aggregates and since 2009 on the rate of inflation (the Law did not regulate in details the content of the Decision). The council was in charge of passing decisions on the conduct of the monetary and foreign exchange policies. Still, in case of disagreement regarding the monetary policy the parliament had the final word. If the council did not reach an agreement, the governor had a right to adopt a decision that he deemed inevitable to prevent endangering of the primary objective, but he had to inform the parliament about the adoption of the final decision.

The limitations on lending to the government were tightened. The law limited lending to the government only for the purpose of repaying loans to the IMF, as well as for overnight budgetary needs. It explicitly prevented buying government securities in the primary market. The provision prescribing the council's deciding on lending to the government, including the terms and conditions of the lending, was abolished. Therefore, terms and conditions were largely unstipulated and subject to agreement between the NBRM and the MoF resulting in lower value for this criterion.

The law strengthened the provisions on the chief executive officer resulting in a higher value of the index for this group of variables (from 0.44 to 0.77 ). The law stipulated the dismissal criteria for the governor. The dismissal could take place under conditions not related to the monetary policy or if the policy was implemented in a non-professional, dishonest, non-accountable, and untimely manner. The governor was not allowed to hold any positions with the government.

The assessment of the provisions of the most recent law, which was passed in 2010 and subsequently amended a couple of times points to a further strengthening of the independence. The index increases from 0.70 to 0.92 . Progress is evident in all clusters, except for the central bank objectives as price stability was already established as the primary objective in the previous law.

To achieve the objectives, the NBRM is assigned a full responsibility for monetary and foreign exchange policy, while the decision on the exchange rate regime became a shared responsibility with the government. Namely, the law stipulates that the government and the NBRM decide on the exchange rate regime without endangering the price stability objective. However, the responsibility for the exchange rate regime is not one of the criteria in the index and does not result in lower scoring, though effectively it implies lower independence. The requirement 
to prepare a formal document on the monetary policy objectives that used to be adopted by the council and then submitted to the parliament was abolished. The law does not contain a specific provision on the resolution of conflict, but overall impression from the Law is that the final decision rests with the council of the NBRM. Also, it empowers the governor to make decisions in case the votes of the members of the council are divided equally. Strengthened provisions regarding the resolution of conflict led to increased value of the index for the policy formulation group (from 0.45 to 0.75 ). The new law did not introduce any specific provisions providing for the NBRM involvement in the budgetary process.

The value of the chief executive criteria group remained unchanged (0.77) as there were not many changes in the legal provisions pertaining to the variables in this group. The governor is appointed by the parliament at a proposal of the president of the state for a term of office of 7 years, implying longer term of office than the executive branch. The dismissal of the governor remained in the hands of the parliament at a proposal of the president of the state, but upon consultations with the NBRM council. A novelty was that the proposal for dismissal could be also submitted directly by the council and that the governor and other members of the council could be re-elected without any restrictions on the number of reelections (previously governor and vice-governors were allowed to be re-elected only once, and the other members were not allowed to be re-elected).

The law further strengthened the limitations on lending by prohibiting lending to the government, with an exception of the intraday lending. The NBRM can approve intraday loans to the government for smooth execution of payment transactions backed by government securities. The NBRM can purchase government securities only in the secondary market for the monetary policy purposes. The law does not specify limits on intraday lending and detailed lending terms and conditions, but the highest value for all the criteria in the lending group is assigned having into consideration that the purpose of lending is smooth functioning of the payment system rather than funding budgetary needs. In practice, the government has not resorted to intraday borrowing from the central bank.

The law brought improvements in other segments that are not directly captured by the index. The independence regarding the conduct of the monetary policy was reinforced by prescribing that members of the council and employees of the bank should not seek or receive any instructions from the government or any other legal or natural person. The number of executive members of the council was increased from 3 to 4 , with all vice-governors becoming members of the council. The law adopted in 1992 defined that the council is composed of the governor and 8 external members, and the law adopted in 2002 stipulated 3 executive 
members (the governor and 2 vice-governors) and 6 non-executive members. The former provision granting the right to the minister of finance to participate in the sessions of the council was replaced by a new provision stating that attendance of other members is only by an invitation of the bank. Still, the minister of finance and the governor are required to regularly meet with a view to coordinating monetary and fiscal policies. Furthermore, the government is obliged to consult with the NBRM when drafting laws and regulations that may have implications for the objectives and functions of the bank, and the bank is allowed to express its views on these draft laws when they are discussed in the parliament.

Yet, it should be emphasized that the most recent law posed challenges for the central bank independence in two key segments - responsibilities for the foreign exchange regime and the process of appointment of the non-executive members of the NBRM council. The decision on the foreign exchange regime became a shared responsibility between the MoF and the NBRM. Still, the decision on the foreign exchange regime should not endanger the primary objective of price stability. In practice, there is no formal document (available to the public) on the agreement between the two institutions about the foreign exchange regime. Since 2012, the NBRM has started preparing and publishing a medium-term strategic plan of the central bank, adopted by the Council, which clearly determines a stable exchange rate as the chosen monetary strategy for achieving price stability. Although this provision is in line with the European legislation, it implies a step back as the NBRM used to be in charge of the foreign exchange regime and policy.

The most recent law stipulates that executive members of the NBRM council of the (vice-governors) are appointed by the parliament at the proposal of the governor, and the non-executive members are appointed by the parliament at the proposal of the government. According to the 2002 law, the non-executive members were appointed by the parliament at the proposal of the president of the state. Given that the council is composed of 9 members - 4 executive (governor and three vice-governors) and 5 non-executive members, this procedure of appointment may imply lower independence from the government in formulating and implementing monetary policy. This change is not reflected in the index because the index does not cover the process of appointment of the entire council of the bank- it focuses only on the governor.

The comparison of these results for the measurement of independence of the NBRM with findings of the previous research work, which also apply the Cukierman index, points to some differences. Bogoev (2007) and Jankoski (2008), who assess the independence according to the law on the central bank in force during 
2002-2010, assess the value of the index at 0.87 and 0.60 , respectively. The major part of the difference among the indices from these three sources can be attributed to the scoring for the lending limitations group, with Bogoev assigning the highest score of 1 for all the dimensions of the lending limitations, which is not the case for the other two sources. Different values of the indices indicate that although the legal index should provide pretty straightforward assessment of the legal aspect of independence, this is not always the case. A measurement is dependent on the subjective interpretation of the legal provisions, especially when the law is not very specific, providing a room for different considerations.

\section{B. Modified Cukierman Index}

The measurement of the NBRM independence is also performed on the basis of the modified Cukierman index of Jacome and Vazquez (2005). This index, which is also founded exclusively on the legal or de jure aspect, maintains the four main groups of criteria of the Cukierman index, but modifies some of the individual criteria trying to capture some specific aspects relevant for transition economies. It also adds a new group of criteria to measure accountability of the central bank since it enhances bank's credibility and the effectiveness of the monetary policy.

The MCI introduces a couple of innovations to the basic Cukierman index, including the following: (i) focus on appointment and dismissal of the entire bank council, rather than on the governor, as the legal power of the governor represents only a fraction of the power within the council, and the procedures for governor and for the rest of the members of the council may differ; (ii) inclusion of the criterion on formulation of the exchange rate policy, which is a very important aspect for small and open economies; (iii) a shift from involvement of the central bank in the budgetary process to its involvement in public debt policy; (iv) inclusion of the criterion on central bank facilities to deal with banking crisis, as bigger involvement in banking crisis can be treated as quasi-fiscal operation endangering the monetary autonomy; (v) inclusion of the criterion on financial autonomy as it strengthens the conduct of the monetary policy and systemic liquidity management; and (vi) addition of a group of criteria for accountability, which represents an integral component of the central bank autonomy.

As the Cukierman index, the MCI assigns the highest weight to the lending limitations group of criteria, as lending is considered to be the main source of inflation. Still, the weight is lower compared to the basic index (40 against 50 percent) because the MCI includes a new group of criteria on accountability. Within the lending group, the highest weight is assigned to the securitized lending, while the 
basic index assigns the highest value to the non-securitized lending. The weight of 20 percent is assigned to the modality of appointment and dismissal of the bank's council. The dismissal has the highest weight within the group since this dimension is considered to be instrumental for political autonomy (this is not the case in the basic index). A weight of 15 percent is assigned to objectives and to policy formulation groups, and 10 percent to the accountability group.

The MCI points to similar conclusions as the basic index. The independence of the NBRM has increased over time with a value of the index rising from 0.70 to 0.95 , which represents a high level of central bank independence (a detailed assessment is presented in Appendix 1). The independence has increased along all five dimensions captured by the index. Further room for strengthening of the independence remains in the area of policy formulation, i.e. the decision on the exchange rate regime and central bank involvement in the debt management process.

Table 2: Modified Cukierman Index of Independence

\begin{tabular}{lrrrr}
\hline Description of variable & Weight & 2011 & $2002-2010$ & $1992-2001$ \\
\hline Central bank board & 0.20 & 1,00 & 1,00 & 0,90 \\
\hline Central bank objectives & 0.15 & 1,00 & 1,00 & 0,75 \\
\hline Policy formulation & 0.15 & 0,64 & 0,62 & 0,46 \\
\hline Central bank lending & 0.40 & 1,00 & 0,72 & 0,65 \\
\hline Limitations on advances & 0.15 & 1,00 & 0.67 & 0.67 \\
\hline Lending to government & 0.30 & 1.00 & 0.75 & 0.75 \\
\hline Who decides financing conditions to government & 0.10 & 1.00 & 0.33 & 1.00 \\
\hline Beneficiaries of central bank financing & 0.10 & 1,00 & 1,00 & 1,00 \\
\hline Interest rates in advances or lending & 0.10 & 1.00 & 0,50 & 0,50 \\
\hline Lender of last resort & 0.15 & 1.00 & 0.75 & 0.50 \\
\hline Financial autonomy & 0.10 & 1.00 & 1.00 & 0 \\
\hline Accountability & 0.10 & 1,00 & 1,00 & 0,75 \\
\hline Total index value & & 0,95 & 0,83 & 0,70 \\
\hline
\end{tabular}

Source: Author's calculations.

The value of the $\mathrm{MCI}$ is somewhat higher compared to the basic index. The modified index points to higher independence in the area of appointment and dismissal of the governor and other members of the council. The higher score is due to the fact that MCI gives the highest score if the mandate is longer than the presidential term, unlike the basic index where the highest score is given if the mandate is at least 8 years. The value for the dismissal is also higher because in 
the MCI the focus is on the entire council (not exclusively the governor). This is particularly the case for the period 1992-2001. Namely, according to the law of 1992, the dismissal of the governor was a double process (president and legislature), which under MCI has the highest value, but without clear criteria on dismissal. However, for the other members of the council there were no provisions regarding the dismissal, which can be interpreted as an absence of possibility for their dismissal. Similarly, according to the MCI, the highest value is assigned if the governor is appointed through a double process with the involvement of the parliament or council of the bank and not directly by the executive branch. The basic index gives highest value if the governor is appointed by the council of the bank.

Regarding the objectives, there are no significant changes in the scoring between the basic and modified index. Differences in the scoring for the policy formulation are due to the addition of a new dimension (exchange rate policy) and different weighting structure of the modified index with the highest weight being given to the manner of policy formulation (as opposed to the basic index that assigns the highest weight to the resolution of conflict). In the initial period under analysis, the exchange rate policy, same as the monetary policy, was determined by the parliament. While objectives of the monetary policy were determined on the basis of the proposal of the NBRM, the foreign exchange regime and policy were determined on the basis of the proposal of the government. The parliament used to adopt an annual Decision on the foreign exchange policy and projection of the balance of payments that determined the foreign exchange regime and policy, including the measures aimed at supporting the export and limiting the import. It is important to note that the Decisions were not always fully consistent with the Constitution where a stable exchange rate was determined as one of the objectives of the NBRM. The exchange rate regime was changed on a couple of occasions without any amendments to the Constitution. The legal provisions valid throughout 2002-2010 shifted the responsibility for the monetary and foreign exchange policies to the central bank. The council of the NBRM used to adopt the Decision on the goals of the monetary policy that clearly stated the price stability as the primary objective and stable exchange rate as the intermediate objective subordinated to the price stability. Since 2011, the foreign exchange regime has become a shared responsibility between the NBRM and the MoF, which resulted in a lower value for this criterion. Still, the value for the entire group on policy formulation increased due to the strengthened provisions on conflict resolution in case of disagreements on monetary policy.

The scoring for the lending group is not much different, except that this group now includes two new dimensions - a lender of last resort and financial auton- 
omy. The provisions on financial support to the banking system have become tighter over years. Currently, commercial banks have access to the lender of last resort facility, approved only to solvent financial institutions, for liquidity purposes, up to 180 days. Financial autonomy has also been strengthened. Initially, the central bank was involved in quasi-fiscal operations by being obliged to rediscount loans extended by the banks to the enterprises for specific purposes. In 1994, this practice was abolished and financial autonomy was strengthened. Currently, the law sets the amount of the central bank capital that can be further increased by way of decision of the parliament upon proposal of the central bank. The capital cannot be reduced. In case of losses, they are first covered from the general reserves of the bank, and then from the capital which then has to be recovered by the government in cash or by issuing government securities with market interest rate. The general reserves are used only for covering losses and are created from the profit of the central bank. Seventy percent of the profit can be distributed in general reserves until reserves reach the capital of the bank, and then only 15 percent.

Accountability of the NBRM, evaluated on the basis of reporting to the parliament and executive branch on the monetary policy and the disclosure of financial statements, is at a high level. Namely, throughout the entire analyzed period, the NBRM has been required to provide at least annual and semi-annual reports to the parliament. The most recent law further enhanced the accountability by stipulating that the annual report has to be submitted to the parliament and the minister of finance, and that the NBRM is required to publish monthly balance sheets, regular quarterly reports on the monetary policy, and annual financial stability reports. The parliament is also authorized to ask the governor to participate in the parliamentary session on the monetary policy and financial system. A detailed financial statement prepared in accordance with international standards and approved by an authorized auditor has to be published and submitted to the parliament, the president of the state, the prime minister, and the minister of finance. The exception was the law passed in 1992 that did not stipulate detailed requirements regarding the financial statements.

The modified Cukierman index was also calculated by Bogoev (2007) based on the legal provisions of the law passed in 2002. His index points to somewhat higher independence due to the higher scoring for the lending limitations. For the rest of the criteria there are no differences in the scoring. 


\section{Legal versus actual independence}

As the assessment of the NBRM independence is based on the legal provisions, the indices can serve only as an indication of the actual independence of the central bank. Thus, the results on measurement of independence should be interpreted with caution. First, general indices reflect different perceptions about the importance of the dimensions that should be included in the index, leading to different structure and weights of individual dimensions that produce different assessments. Second, central bank laws can have general provisions subject to wide interpretations and conclusions by the evaluators. Third, even if the laws are clear and specific, the practice may differ on the back of different political cultures, resulting in a gap between the de jure and de facto independence. This is more likely to be the case in developing economies commonly faced with lower de facto independence. In some cases, the actual independence may be higher compared to the legal, which, to a great extent, depends on the personality and the professional background of the governor, but also on the personality and professional background of the top officials in the government (in particular of the minister of finance). Still, the legal indices are a valuable indicator that at least points to the intention of the executive and legislative branch as regards the level of independence meant to be provided to the central bank.

Measurement of the actual independence is not an easy task. It is most commonly measured through the rate of turnover of governors and questionnaires filled in by central bankers. A higher turnover of governors is interpreted as lower independence because the shorter term of office of the governor pinpoints a higher probability of exerting political pressures on the governor and subjecting the monetary policy to short-term economic policies. Having said this, the longer term of office is not a guarantee for independence as subservient governors may be prone to longer mandates.

The turnover rate of governor, as introduced by Cukierman, Webb and Neyapti (1992), represents an average term of office of central bank governors and is calculated as the number of governors in a certain period of time divided by the length of the period. Accordingly, the rate is expressed in years or fractions of years. The maximum threshold for the turnover rate is set at 0.2 to 0.25 , i.e. one governor every 4 to 5 years, and the rate exceeding this threshold is considered a large turnover. On the other hand, a very long term of office may point to a subservient role of governor. While the minimum threshold of the turnover rate has not been identified in the literature, the provision of the Maastricht Treaty that the duration of the office of the members of the ECB Executive Board is 8 
years, without a possibility for reappointment, can be interpreted as a minimum threshold rate of 0.125 (Dvorsky, 2000).

Based on the criterion of a turnover rate of governors, the actual independence of the NBRM appears to be high. The turnover rate is 0.17 , meaning roughly one governor every 6 years. All governors, except one, have served a full mandate of 7 years. The first governor after the independence of the country served 5 years. The term of office of all governors was longer than the electoral cycle and the term of office of the president of the state, which is 5 years. Still, this is only one angle through which the actual independence can be proxied and therefore cannot be used as a strong evidence of the de facto independence. Also, the observation period is rather short for deriving firm conclusions.

\section{Inflationary developments}

First years of the transition were marked by high and volatile inflation stemming from non-disciplined macroeconomic policies, as well as political factors. Political independence of the country in 1991 was established in an environment of hyperinflation, unfavourable external sector developments, continuous depreciations of the exchange rate of the domestic currency against the Deutsche mark, the existence of unofficial currency exchange market, and almost no foreign reserves. Expansionary fiscal policy, on the back of contraction of economic activity and eroded tax base, in combination with loose monetary policy, were not conducive to stabilization of inflationary developments.

\section{Graph 1: Inflation, average}

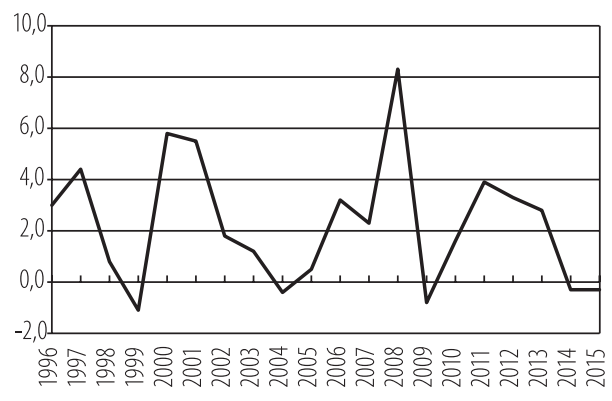

Source: NBRM
Amidst weak legal protection from the executive branch, the central bank performed quasi-fiscal operations that implied weak control over monetary aggregates and subsequently high inflationary pressures. The central bank was required to provide loans to banks to be channelled to specific economic sectors determined by the parliamentary decision. Thus, the control over the monetary base was very weak. Legal provisions on the objectives and functions of the central bank valid during this turbulent period did not provide adequate protection of the 
bank from the executive branch. The objectives of the monetary policy, as well as foreign exchange regime and policy were decided by the parliament. Price stability was not even stated in the law as one of the objectives of the central bank. The law allowed central bank financing of the government up to 5 percent of the Budget.

Inflationary trends were tamed at the beginning of 1996 amidst the implementation of a tight and consistent policy mix within the framework of the first stabilization arrangement with the International Monetary Fund (hereinafter: IMF). One of the elements of the first IMF program was amendment to the Law on the NBRM to strengthen the central bank independence. Tightening the criteria on lending to the government, abolishing the practice of provision of loans to the companies by the central bank, and increased number of executive members in the Council of the bank (vis-à-vis the non-executive members) helped the central bank to establish a control over monetary aggregates and bring down inflation to a single-digit level.

Since then, price stability has been maintained in light of the implementation of the exchange rate targeting strategy, a prudent mix of macroeconomic policies, which to a certain extent reflects the IMF involvement through different arrangements. The independence of the NBRM throughout the years has been reinforced and has made a positive contribution towards preserving price stability. Further strengthening of the limitations on the government borrowing, clearly stipulating price stability as the primary objective of the central bank, assigning a full responsibility for monetary policy to the central bank, strengthening personal independence of the governor and other members of the council of the bank, have helped in implementing an adequate policy mix. Although the most recent changes of the legal framework concerning the exchange rate regime and appointment of the non-executive members of the council of the bank point to some potential risks, still up to now there have not been any negative implications for the conduct of the monetary policy.

A combination of prudent monetary, fiscal, exchange rate, and income policies proved to be a successful mix in bringing and keeping inflation down thus creating a stabile macroeconomic environment. A low single-digit inflation rate that was achieved in 1996 was maintained almost throughout the whole transition period, being one of the main characteristics of the transition process of the Macedonian economy. An average inflation for the period 1996-2015 amounted to $2.3 \%$, which is close to the average level of inflation in the EU countries and is a great advantage compared to other transition countries. 
Temporary pick up in prices observed in a couple of periods was driven mainly by the supply side factors. Higher inflation was registered during 2000-2001 stemming from the introduction of the value added tax and psychological factors related to the domestic security crisis. Also a pick-up in prices occurred in 2008 due to the global price shock reflecting the rising demand for commodities by emerging market economies, as well as supply constraints. Thus, average inflation reached $8.3 \%$ in 2008, driven by the global rise of food and energy prices and to some extent by the domestic demand. Some inflationary pressures again became evident in the second half of 2010, emanating mainly from the tight global supply reflecting unfavourable global weather conditions and geopolitical tensions in the Middle East and South Africa.

Apart from the first years of transition, a mix of prudent monetary policy, underpinned by a relatively strong legal mandate of the central bank, and a prudent fiscal policy have resulted in low and stable inflation. Overall, inflation dynamics in the Macedonian economy was determined chiefly by the supply side factors, such as price liberalization process, tax changes, movements in the world prices of primary commodities, obligations related to the World Trade Organization membership, and the Stabilization and Association Agreement with the European Union. Given the high openness of the Macedonian economy, movements in the world prices of food and energy have been a very important factor influencing the price dynamics. Global shocks in the commodity prices have been highly transmitted in the domestic price level, especially the food prices as food has had a significant weight in the inflation index. The level of transmission of the global price shocks varied depending on the stage of the business cycle.

\section{Conclusion}

Central bank independence is considered a key precondition for achieving central bank primary objective of price stability. Adequate institutional mechanisms that safeguard central bank from short-term political considerations are instrumental in preserving central bank's control over monetary aggregates, credibility of the central bank and subsequently price stability.

Legal independence of the NBRM is investigated on the basis of the index of Cukierman, Webb and Neyapti (1992) and the modified Cukierman index of Jacome and Vazquez (2005). Both indices indicate that the legal independence of the NBRM has increased over the years and that the current legal framework provides a high level of independence. The first law on the NBRM adopted in 1992 provided only a moderate level of independence that was later strengthened. 
Progress has been evident across all variables included in the indices. Strengthening of the legal mandate of the bank, personal independence of the governor and other top personal of the bank, institutional independence from the executive branch and strict limitations on government borrowing have helped in implementing adequate policy mix conducive to price stability. Yet, it should be emphasized that the current law poses some challenges in two key segments - responsibilities for the foreign exchange regime and the process of appointment of the non-executive members of the council of the NBRM. Other areas that deserve attention with a view to further enhancement of the central bank independence are the term of office and the process of appointment and dismissal of the governor, as well as the role of the central bank in the government's budgetary process and debt management.

Still, as the assessment of independence of the NBRM is based on the legal provisions, the indices can serve only as an indication of the actual independence of the central bank. Thus, the results on the measurement of independence should be interpreted with caution. Measurement of the actual independence seems a challenging task and it is usually measured through the rate of turnover of governors and questionnaires filled in by central bankers. Based on the criterion of a turnover rate of governors, the actual independence of the NBRM appears to be high. The turnover rate is 0.16 , meaning roughly one governor every 6 years. Still, this is only one angle through which the actual independence can be proxied and therefore cannot be used as a strong evidence of the de facto independence. Also, the observation period is rather short for deriving firm conclusions. 


\section{APPENDIX I}

Table 1: Measurement of Independence of NBRM-Modified Cukierman Index

\begin{tabular}{|c|c|c|c|c|c|}
\hline Description of variable & Weight & $\begin{array}{l}\text { Numerical } \\
\text { coding }\end{array}$ & 2011- & $\begin{array}{l}2002- \\
2010\end{array}$ & $\begin{array}{l}1992- \\
2001\end{array}$ \\
\hline Central Bank Board & 0.20 & & 1,00 & 1,00 & 0,90 \\
\hline 1. Term of office of governor & 0.20 & & 1.00 & 1.00 & 1.00 \\
\hline More than presidential period & & 1.00 & 1.00 & 1.00 & 1.00 \\
\hline The period does not coincide & & 0.67 & & & \\
\hline Same period as the executive brunch & & 0.33 & & & \\
\hline Less than executive branch or not specified in the law & & 0 & & & \\
\hline 2. Who appoints the Governor? & 0.20 & & 1,00 & 1,00 & 1,00 \\
\hline $\begin{array}{l}\text { Double process (Executive/ Legislative), or through the Central } \\
\text { Bank Board if also appointed in a double process, or for longer or } \\
\text { overlapped periods with respect to the executive brunch }\end{array}$ & & 1.00 & 1,00 & 1,00 & 1,00 \\
\hline $\begin{array}{l}\text { The executive brunch directly or through the Central Bank Board, } \\
\text { when this is directly appointed by the executive brunch }\end{array}$ & & 0 & & & \\
\hline 3. Appointment and term of office rest of the Board & 0.20 & & 1,00 & 1.00 & 1,00 \\
\hline More than presidential period or for a non-defined period & & 1.00 & 1,00 & 1.00 & 1,00 \\
\hline For the same period as the President of the Republic with overlap & & 0.75 & & & \\
\hline Double process for the same period & & 0.50 & & & \\
\hline $\begin{array}{l}\text { Executive and private sector appoint the majority of directors for } \\
\text { same period or less }\end{array}$ & & 0.25 & & & \\
\hline $\begin{array}{l}\text { Executive brunch appoints the majority for the same period or } \\
\text { less }\end{array}$ & & 0 & & & \\
\hline 4. Dismissal of Board members & 0.30 & & 1,00 & 1,00 & 1.00 \\
\hline $\begin{array}{l}\text { Double process approved by the Senate or a qualified majority } \\
\text { and for violations codified in legislation }\end{array}$ & & 1.00 & 1,00 & 1,00 & 1.00 \\
\hline By an independent Central Bank Board & & 0.75 & & & \\
\hline $\begin{array}{l}\text { Double process with simple majority, based on policy decisions } \\
\text { or due to subjective reasons }\end{array}$ & & 0.50 & & & \\
\hline $\begin{array}{l}\text { By executive brunch or subordinated Central Bank Board due to } \\
\text { legal reasons }\end{array}$ & & 0.25 & & & \\
\hline $\begin{array}{l}\text { By executive brunch or subordinated Central Bank Board due to } \\
\text { policy or subjective reasons, or no legal provision }\end{array}$ & & 0 & & & \\
\hline 5. CEO allowed to hold another office in government & 0.10 & & 1,00 & 1,00 & 0,00 \\
\hline Prohibited by law & & 1.00 & 1,00 & 1,00 & \\
\hline Not allowed unless authorized by executive brunch & & 0.50 & & & \\
\hline No prohibition for holding another office & & 0.00 & & & 0,00 \\
\hline Central Bank objectives & 0.15 & & 1,00 & 1,00 & 0,75 \\
\hline 6. Fundamental objective & 1 & & 1,00 & 1,00 & 0.75 \\
\hline Price stability is the single or primary objective & & 1.00 & 1,00 & 1,00 & \\
\hline $\begin{array}{l}\text { Price stability together with non-conflicting objectives but } \\
\text { without priority }\end{array}$ & & 0.75 & & & 0.75 \\
\hline $\begin{array}{l}\text { Price stability plus other goals including stability of financial } \\
\text { system that may conflict with the former, without priority }\end{array}$ & & 0.50 & & & \\
\hline $\begin{array}{l}\text { Price stability together with objective of economic growth/ } \\
\text { economic development with no priority }\end{array}$ & & 0.25 & & & \\
\hline Objectives do not include price stability & & 0 & & & \\
\hline Policy formulation & 0.15 & & 0,64 & 0,62 & 0,46 \\
\hline 7. Who formulates monetary policy & 0.50 & & 0.67 & 1.00 & 0.67 \\
\hline Central bank has the legal authority & & 1.00 & & 1.00 & \\
\hline Executive brunch holds the final decision on exchange rate policy & & 0.67 & 0.67 & & 0.67 \\
\hline $\begin{array}{l}\text { Central bank participates on monetary policy formulation in } \\
\text { an advisory capacity or faces legal limitations on monetary } \\
\text { instruments or interest rates }\end{array}$ & & 0.33 & & & \\
\hline Government formulates monetary policy alone & & 0.00 & & & \\
\hline
\end{tabular}


Table 1: Measurement of Independence of NBRM-Modified Cukierman Index (continued)

\begin{tabular}{|c|c|c|c|c|c|}
\hline Description of variable & Weight & $\begin{array}{l}\text { Numerical } \\
\text { coding }\end{array}$ & 2011- & $\begin{array}{l}2002- \\
2010\end{array}$ & $\begin{array}{l}1992- \\
2001\end{array}$ \\
\hline 8. Government directives and resolution of conflicts & 0.30 & & 1.00 & 0.40 & 0.40 \\
\hline $\begin{array}{l}\text { Central bank given final authority over issues defined in the law } \\
\text { as objectives }\end{array}$ & & 1.00 & 1.00 & & \\
\hline $\begin{array}{l}\text { Government has final authority over issues not clearly defined as } \\
\text { Central Bank goals }\end{array}$ & & 0.80 & & & \\
\hline $\begin{array}{l}\text { Final decision up to a council whose members are from the } \\
\text { Central Bank, executive brunch, and legislative brunch }\end{array}$ & & 0.60 & & & \\
\hline Legislative brunch has final authority & & 0.40 & & 0.40 & 0.40 \\
\hline $\begin{array}{l}\text { Executive branch has final authority, but subject to due process } \\
\text { and possible protest by Central Bank }\end{array}$ & & 0.20 & & & \\
\hline Executive branch has unconditional authority over policy & & 0.00 & & & \\
\hline 9. Central Bank involvement in debt approval & 0.20 & & 0,00 & 0,00 & 0,00 \\
\hline Approves government debt & & 1.00 & & & \\
\hline Legally required to provide opinion on technical aspects & & 0.5 & & & \\
\hline No involvement at all & & 0 & 0,00 & 0,00 & 0,00 \\
\hline Central Bank lending & 0.40 & & 1,00 & 0,72 & 0,65 \\
\hline 10. Limitations on advances & 0.15 & & 1,00 & 0.67 & 0.67 \\
\hline Advances to government prohibited & & 1.00 & 1,00 & & \\
\hline $\begin{array}{l}\text { Limited by small percentage of government revenues or by } \\
\text { monetary program }\end{array}$ & & 0.67 & & 0.67 & 0.67 \\
\hline $\begin{array}{l}\text { Allowed under lax limits (more than } 15 \text { percent of government } \\
\text { revenues) }\end{array}$ & & 0.33 & & & \\
\hline Allowed without limits & & 0.00 & & & \\
\hline 11. Lending to Government & 0.30 & & 1.00 & 0.75 & 0.75 \\
\hline Not allowed & & 1.00 & 1.00 & & \\
\hline In the secondary market with restricted limits & & 0.75 & & 0.75 & 0.75 \\
\hline In the secondary market with lax or without limits & & 0.50 & & & \\
\hline $\begin{array}{l}\text { In the primary market with limits or approved by Central bank } \\
\text { Board with a qualified majority }\end{array}$ & & 0.25 & & & \\
\hline In the primary market without limits & & 0 & & & \\
\hline 12. Who decides financing conditions to government & 0.10 & & 1.00 & 0.33 & 1.00 \\
\hline Central bank defines terms and conditions & & 1.00 & 1.00 & & 1.00 \\
\hline Defined by law & & 0.67 & & & \\
\hline The law allows negotiations between government and Central Bank & & 0.33 & & 0.33 & \\
\hline Executive decides independently & & 0.00 & & & \\
\hline 13. Beneficiaries of Central bank financing & 0.10 & & 1,00 & 1,00 & 1,00 \\
\hline Only the government & & 1.00 & 1,00 & 1,00 & 1,00 \\
\hline Government plus local governments & & 0.67 & & & \\
\hline All of the above plus public enterprises & & 0.33 & & & \\
\hline All of the above and to the private sector & & 0.00 & & & \\
\hline 14. Interest rates in advances or lending & 0.10 & & 1.00 & 0,50 & 0,50 \\
\hline At market rates & & 1.00 & 1.00 & & \\
\hline Interest rates not specified in the law & & 0.5 & & 0,50 & 0,50 \\
\hline At below market rates & & 0 & & & \\
\hline 15. LOLR & 0.15 & & 1.00 & 0.75 & 0.50 \\
\hline $\begin{array}{l}\text { For liquidity purposes with limitations (up to } 180 \text { days or up to } \\
\text { bank's equity), or no legal provision for emergency lending }\end{array}$ & & 1.00 & 1.00 & & \\
\hline For liquidity at conditions defined by the central bank & & 0.75 & & 0.75 & \\
\hline $\begin{array}{l}\text { Provisions for constructive ambiguity or rediscount of } \\
\text { commercial bank loans }\end{array}$ & & 0.50 & & & 0.50 \\
\hline Open assistance to cope with solvency problems & & 0.25 & & & \\
\hline To finance bank restructuring and/or paying deposit insurance & & 0 & & & \\
\hline 16. Financial autonomy & 0.10 & & 1.00 & 1.00 & 0 \\
\hline Government should maintain central capital integrity & & 1.00 & 1.00 & 1.00 & \\
\hline Government is legally allowed to capitalize the central bank & & 0.67 & & & \\
\hline The law does not allow the government to capitalize the central ban & & 0.33 & & & \\
\hline The Central Bank conducts quasi-fiscal operations & & 0 & & & 0 \\
\hline
\end{tabular}


Table 1: Measurement of Independence of NBRM-Modified Cukierman Index (continued)

\begin{tabular}{|c|c|c|c|c|c|}
\hline Description of variable & Weight & $\begin{array}{l}\text { Numerical } \\
\text { coding }\end{array}$ & 2011- & $\begin{array}{l}2002- \\
2010\end{array}$ & $\begin{array}{l}1992- \\
2001\end{array}$ \\
\hline Accountability & 0.10 & & 1,00 & 1,00 & 0,75 \\
\hline 17. Accountability of Central Banks & 0.75 & & 1.00 & 1.00 & 1.00 \\
\hline $\begin{array}{l}\text { Reports to executive branch and informs at least annually to } \\
\text { Congress }\end{array}$ & & 1.00 & 1.00 & 1.00 & 1.00 \\
\hline $\begin{array}{l}\text { Reports to executive once a year and submits an annual report to } \\
\text { Congress }\end{array}$ & & 0.75 & & & \\
\hline $\begin{array}{l}\text { Annual reports to executive. Informs to the executive branch } \\
\text { whenever fundamental disequilibria emerge, or reports through } \\
\text { the media without specific periodicity }\end{array}$ & & 0.50 & & & \\
\hline Issues annual report at specific time & & 0.25 & & & \\
\hline $\begin{array}{l}\text { Distributes an annual report without establishing particular } \\
\text { period of time for it }\end{array}$ & & 0 & & & \\
\hline 18. Central Bank transparency & 0.25 & & 1.00 & 1.00 & 0 \\
\hline $\begin{array}{l}\text { Discloses detailed financial statements at least once a year with } \\
\text { an certification of an independent auditor }\end{array}$ & & 1.00 & 1.00 & 1.00 & \\
\hline $\begin{array}{l}\text { Disclose consolidated financial statements at least once a year } \\
\text { with seal of Banking Superintendent or other public sector } \\
\text { authority }\end{array}$ & & 0.75 & & & \\
\hline $\begin{array}{l}\text { Discloses financial statements at least once a year, certified by an } \\
\text { internal auditor }\end{array}$ & & 0.50 & & & \\
\hline Publishes partial financial statements & & 0.25 & & & \\
\hline $\begin{array}{l}\text { Does not publish financial statements or the law authorizes } \\
\text { central bank to deviate from international accounting standards }\end{array}$ & & 0 & & & \\
\hline Total index value & & & 0,95 & 0,83 & 0,70 \\
\hline
\end{tabular}

Source: Author's calculations 


\section{REFERENCES}

1. Alesina, A., \& Summers, L.H. (1993). Central bank independence and macroeconomic performance: some comparative evidence. Journal of Money, Credit and Banking, 25(2), 151-162.

2. Bade, R., \& Parkin, M. (1988). Central bank laws and monetary policy. Department of Economics, University of Western Ontario, Canada.

3. Barro, R.J., \& Gordon, D.B. (1983). Rules, discretion and reputation in a model of monetary policy. NBER Working Paper No.1079.

4. Beddies, C.H. (2000). Selected issues concerning monetary policy and institutional design for central banks. IMF Working Paper No.00/140.

5. Berger, H., de Haan, J., \& Eijffinger, S.C.W. (2001). Central bank independence: an update of theory and evidence. Journal of Economic Surveys, 15(1), 3-40.

6. Blinder, A. S. (1998). Central banking in theory and practice (1st ed.), Cambridge: MIT Press.

7. Bogoev, J. (2007). Nezavisnost na centralnite banki-sporedba pomegu zemjite od Jugoistocna Evropa [Independence of the central banks- a comparison among countries of Southeastern Europe]. NBRM Working Paper No.18/2007.

8. Borrero, A.M. (2000). On the long and short of central bank independence, policy coordination, and economic performance. IMF Working Paper No.01/19.

9. Crowe C.W., \& Meade, E.E. (2008). Central bank independence and transparency: evolution and effectiveness. IMF Working Paper No. 08/119.

10. Cukierman, A. (1992). Central bank strategy, credibility and independence: theory and evidence (4th ed.). Chicago, USA: MIT Press.

11. Cukierman, A., Webb, S.B., \& Neyapti, B. (1992). Measuring the independence of central banks and its effect on policy outcomes. The World Bank Economic Review, 6(3), 353-398.

12. Cukierman, A., Kalaitzidakis, P., Summers, L., \& Webb, S. (1993). Central bank independence, growth, investment, and real rates. Carnegie-Rochester Conference Series on Public Policy, 39(1), pp. 95-140.

13. Cukierman, A., Miller, G.P., \& Neyapti, B. (2002). Central bank reform, liberalization and inflation in transition economies: an international perspective. Journal of Monetary Economics, 49, 237-264.

14. Cukierman, A. (2009). Central bank finances and independence-how much capital should a central bank have? In S. Milton \& P. Sinclair (Eds.), The capital needs of central banks. New York, USA: Routledge. 
15. Debelle, G., \& Fisher, S. (1994). How independent should a central bank be? In Fuhrer, J.C (Eds.), Goals, Guidelines and Constraints Facing Monetary Policymakers. Federal Reserve Bank of Boston.

16. Dvorsky, S. (2000). Measuring central bank independence in selected transition countries and the disinflation process. Bank of Finland Discussion Paper No.13.

17. Dvorsky, S. (2004). Central bank independence in Southeastern Europe with a view to future EU accession. Austrian Central Bank, Focus on European Economic Integration, 2, 50-75.

18. Dvorsky, S. (2007). Central bank independence in Southeastern Europe with a view to EU integration-revisited. Austrian Central Bank, Focus on European Economic Integration, 1, 101-114.

19. Eggertsson, G., \& le Borgne, E. (2003). A Political agency theory of central bank independence. IMF Working Paper No. 03/144.

20. Eijffinger, S.C.W, \& Scaling, E. (1993). Central bank independence in twelve industrial countries. Banca Nazionale del Lavoro, Quarterly Review 184, pp.49-89.

21. Eijffinger, S.C.W, \& Stadhouders, P. (2003). Monetary Policy and the Rule of Law. Center for Economic Policy Research, Discussion Paper No.3698.

22. Fry, M. (1998). Assessing central bank independence in developing countries: do actions speak louder than words? Oxford Economic Papers, 50(3), 512-529.

23. Goodhart, C.A.E. (2010). The changing role of central banks. BIS Working Paper No.326.

24. Grilli, V., Masciandaro, D., and Tabelini, G. (1991). Political and monetary institutions and public financial in industrialized economies. Economic Policy 6(13), 341-382.

25. Hinton-Braaten, K. (1994). New Central Banks. Paper presented at the Conference on Constitutional Status of Central Banks in Eastern Europe, University of Chicago Law School.

26. Hochreiter, E. (1994). Central Banking in Economies in Transition. In T. Willett, R. Burdekin, R. Sweeney \& C. Wihlborg, Establishing Monetary Stability in Emerging Market Economies. S.l.: Westview press.

27. Hochreiter, E., \& Riesinger, S. (1995). Central Banking in Central and Eastern Europe-Selected Institutional Issues. ECU Journal, 32, 17-22.

28. Jacome, L., and Vasquez, F. (2005). Any Link Between Legal Central Bank Independence and Inflation? Evidence from Latin America and the Caribbean, IMF WP, No.05/75.

29. Jankoski, B. (2010). Trends and challenges of the contemporary central banking- a case study for National Bank of the Republic of Macedonia. Saarbrucken: VDM Verlag Dr. Muller Gmbh \& Co.KG. 
30. Kydlan, F., \& Prescott, E. (1977). Rules rather than discretion: the inconsistency of optimal plans. Journal of Political Economy, 85(3), 473-491.

31. Laurens, B., \& Piedra, E. (1998). Coordination of monetary and fiscal policies. IMF Working Paper No. 98/25.

32. Lybek, T. (1999). Central bank autonomy and inflation and output performance in the Baltic States, Russia and other Countries of the Former Soviet Union, 1995-1997. IMF Working Paper No.99/4.

33. Loungani, P., \& Sheets, N. (1997). Central bank independence, inflation and growth in transition economies. Journal of Money, Credit and Banking, 29(3), 381-399.

34. Maliszewski, W. (2000). Central bank independence in transition economies. Economics of Transition, 8(3), 749-789.

35. Mishkin, F. (2011). What should central banks do? Federal Reserve Bank of St. Louis Review 8(6), 1-13.

36. Niemann \& von Hagen. (2008). Coordination of Monetary and Fiscal Policies: A Fresh Look at the Issue. Swedish Economic Policy Review, Vol. 15 ( 1$), 89-124$.

37. Neyapti, B. (2001). Central bank independence and economic performance in Eastern Europe. Economic Systems, 25(4), 381-399.

38. Persson, T., \& Tabellini, G. (1993). Designing institutions for monetary stability. Carnegie-Rochester Conference on Public Policy, 39, 53-84.

39. Radzyner, O., \& Riesinger, S. (1997). Central bank independence in transition: legislation and reality in Central and Eastern Europe. Austrian Central Bank, Focus on Transition, 1, 55-90.

40. Rogoff, K. (1985). The optimal degree of commitment to a monetary target. Quarterly Journal of Economics, 100(4), 1169-1190.

41. Wagner, H. (1998). Central banking in transition economies. IMF Working Paper No. 98/126.

42. Wagner, H. (2000). Controlling inflation in transition economies: the relevance of central bank independence and the right nominal anchor. Atlantic Economic Journal, 28(1), 60-70.

43. Walsh, C.E. (1998). Optimal contracts for central bankers. American Economic Review, 85 (1), 150-67. 